\title{
THE ANXIETY OF PERIMENOPAUSE WOMEN IN FACING MENOPAUSE
}

\author{
Meilita Enggune ${ }^{1}$, Elizabeth Purba ${ }^{1}$, Stilly Nathalia Kakumboti ${ }^{1}$ \\ ${ }^{1}$ Academic of Nursing Bethesda Tomohon, Sulawesi Utara, Indonesia \\ Correspondance: lita_lovejc@yahoo.co.id
}

\begin{abstract}
Anxiety is an unclear feeling, uncertain, and but is not dangerous. In adults, anxiety is caused by things that threaten their self-concept. For example, women who are facing menopause, they may be anxious due to a decline in reproductive function, so they need social support to prevent anxiety. The purpose of this study was to determine the anxiety level of perimenopausal women in facing menopause. The research method used was descriptive research design with a sample of 105 people. The results showed that $36.19 \%$ of perimenopausal women experienced mild anxiety levels, $57.14 \%$ experienced moderate anxiety levels, $5.71 \%$ experienced severe anxiety levels, and $0.96 \%$ of perimenopausal women experienced severe panic anxiety levels. It can be concluded that there are women who experience anxiety in facing menopause. Family support, especially husbands, is needed to set daily food diets such as carbohydrates, reduce protein consumption, reduce consumption of fatty foods, high fiber, vitamin $\mathrm{C}$, and calcium, and exercise to reduce complaints related to menopausal symptoms.
\end{abstract}

Keywords: Anxiety, Menopause, Perimenopause.

\section{INTRODUCTION}

Increasing human welfare affects life expectancy, including women, so the number of women experiencing menopause increases. Around 50 million women experience menopause every year. The number of women aged 50 years and over is estimated to increase from 500 million to more than 1 billion by 2030. In Asia, according to data from the World Health Organization (WHO), in 2025 the number of elderly women would increase from 107 million to 373 million (Kasdu, 2010). Climacteric, is a transitional period between the period of reproduction and the period of Senium. This period is also called premenopausal, women's ages around 40 years, characterized by irregular menstrual cycles, and relatively large menstrual bleeding. The menstrual pattern shows irregular individual variations, and shortening the menstrual cycle may be the earliest sign. Ovary progressively does not respond to gonadotropin stimulation, and the FSH 
concentration has increased in the cycle follicular phase (Joseph and Nugroho, 2011).

Many women report psychological symptoms as a problem in the climacteric period. One of the symptoms is anxiety, for perimenopausal women and she works in a very stressful environment, it may cause difficulties. Personality, cultural factors, and attitudes toward menopause clearly affect the incidence of psychological symptoms in the climacteric period. Most of the aging processes in women occur in the menopause phase (Glasier and Gebbie, 2006). The purpose of this study was to determine the anxiety level of perimenopausal women in facing menopause.

\section{METHODS}

This research used a descriptive quantitative research design. The population in the study were perimenopausal women aged 40-55 years, located in the Danowudu Health Center, Bitung City, 105 women involved in this study. The sampling technique was the Saturated Sampling method. Respondents were explained about the purpose of the study, were asked to sign a letter of consent to become respondents, and fill out a questionnaire. Data collection was done using a questionnaire, the Hamilton Rating Scale for Anxiety (HRS-A) method. Respondents' answers were given codes, scores and categories became mild, moderate, severe and panic anxiety. Data were analyzed using percentages and presented in table form. 


\section{RESULTS}

This section presents the study findings in table form and diagrams.

Table 1. The level of anxiety of perimenopause women

\begin{tabular}{ccc}
\hline Levels of anxiety & F & \% \\
\hline Normal & - & - \\
Mild & 38 & $36,18 \%$ \\
Moderate & 60 & $57,14 \%$ \\
Severe & 6 & $5,71 \%$ \\
Panic & 1 & $0,96 \%$ \\
\hline Total & 105 & $100 \%$ \\
\hline
\end{tabular}

The results showed that there were 38 respondents $(36.19 \%)$ who experienced mild anxiety, 60 respondents $(57.14 \%)$ in the moderate level, 6 respondents $(5.71 \%)$ who experienced severe anxiety, 1 respondent $(0.96 \%)$ with panic anxiety

The diagrams of the characteristic of respondents

a) Age

Diagram1. Respondents' ages

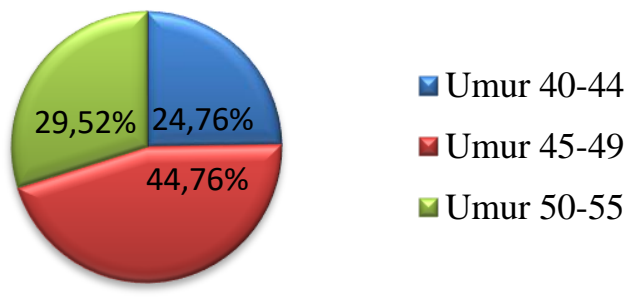

Diagram 1 shows that the majority respondents $(44.76 \%)$ were $45-49$ years $(n=47)$ 
b) Marriage status

Diagram 2. Marriage status

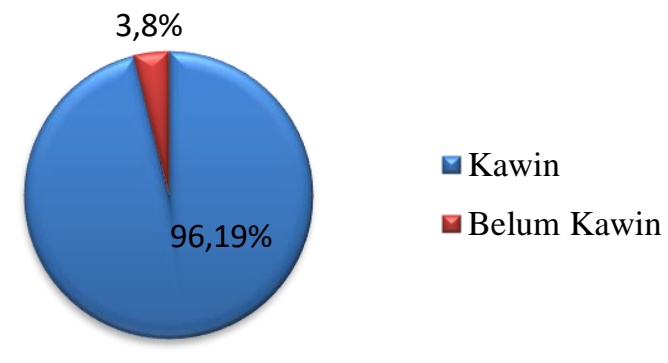

The majority of respondents were married (96.19\%), the rest of them were single $(3.8 \%)$.

c) History of menarche

Diagram 3. History of menarche

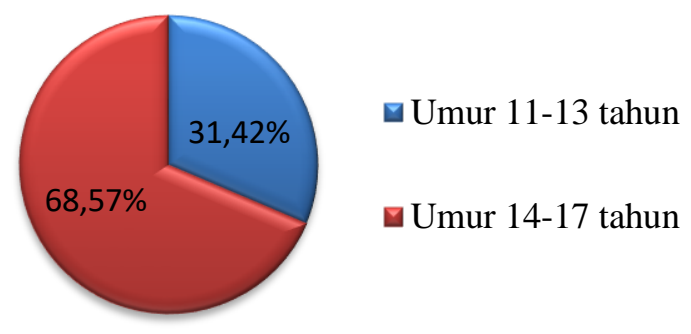

The majority of women having their menarche at the age of 14-17 years $68.57 \%$, while a little of them in $11-13$ years $(31.42 \%)$

\section{DISCUSSION}

The results showed that the majority of respondents experienced mild anxiety, and there were few experiencing severe and panic anxiety. These findings are in line with research by Fitriana (2014) about the anxiety level of perimenopausal women in facing menopause in Kramat Hamlet, Trangsang District, Gatak Sukoharjo. 
Tetti and Cecep (2015) stated that the majority of respondents experienced a mild level of anxiety of 16 respondents (42\%). In contrast Dwi Septi Ambarwati's research found that most perimenopausal respondents experienced moderate anxiety levels (50\%) . in Blekik Sardonoharjo Village Ngaglik Sleman district in 2015.

The results showed that the majority of perimenopausal women in the Danowudu PHC experienced moderate levels of anxiety. According to Glasier and Gebbie 2006, personality, cultural factors, and attitudes toward menopause affect the incidence of psychological symptoms during perimenopause. Most of the aging processes in women occur in the menopause phase (Glasier and Gebbie, 2006). The negative opinion about menopause included that menopause is the beginning of a decline in sexual organ function, become elderly, loss of feminine and sexual qualities, this thought might influence women's readiness to face menopause. The role of the family is very important to support women in the menopause phase. Women who are less informed about menopause cause a negative outlook of this period of life. Culture also influences the readiness of women to face menopause, for example, the Patriarchal culture that perceived menopause is associated with the inability of women to provide sexual satisfaction to men. Preparation is needed both physical and psychological during menopause is a natural thing for all women. The need for daily dietary arrangements such as carbohydrates, reduce protein consumption by up to $15 \%$ of the number of calories, reduce the consumption of fatty foods, high in fiber, vitamin $\mathrm{C}$, and calcium. exercise to reduce symptoms arising from menopausal. Mild anxiety, anxiety associated with everyday tension, causing a person to 
become alert, the results of the study showed 38 respondents (36.19\%) experienced mild anxiety. Moderate anxiety, anxiety that focuses on issues that are important and overrides things that are not priorities, but still directed and selective. Based on the results of the study 60 respondents $(57.14 \%)$ experienced moderate anxiety. Severe anxiety tends to focus on something detailed and specific, and cannot think of anything else, based on the results of the study 6 respondents $(5.71 \%)$ experienced severe anxiety. Panic anxiety, the level of panic anxiety associated with shock, fear, and tremor due to loss of control, based on the results of the study 1 respondent $(0.96 \%)$ who experienced panic anxiety.

\section{CONCLUSION}

The conclusion of this study is that the anxiety level of perimenopausal women facing menopause varies and most experience moderate anxiety. Preparing and having social support for perimenopausal women is very important to avoid anxiety.

\section{REFERENCES}

Anna Glasier \& Ailsa Gebbie. 2005. Keluarga Berencana dan Kesehatan Reproduksi. Jakarta: EGC

Aprillia, N.I \& Puspitasari N. 2007. Factor yang Mempengaruhi Kecemasan pada Wanita Perimenopause. Jurnal of publich health, Vol.4, No. 1, UNAIR

Arikunto, S. 2013. Prosedur Penelitian Suatu Pendekatan Praktik. Jakarta : Rineka Cipta

Asmadi. 2008. Teknik Prosedural Keperawatan: Konsep dan Aplikasi Kebutuhan Dasar Klien. Jakarta: Salemba Medika

Errol, R, Norwits \& John, O, Scharge. 2008. Obstetrics and Gynecology at a Glance. Penerbit Erlangga 
Meilita Enggune: The Anxiety of Perimenopause Women in Facing Menopause

Hidayat, A.A. 2014. Metode Penelitian Kebidanan Dan Teknik Analisis Data. Jakarta : Salemba Medika

Hidayat, A.A. 2010. Riset Keperawatan dan Teknik Penulisan Ilmiah. Jakarta: Salemba Medika.

Joseph, Nugroho, M. 2010. Catatan Kuliah Ginekologi dan Obstetri (obsgyn). Yogyakarta: Nuha Medika

Kasdu, Dini. 2010. Kiat Sehat dan Bahagia di Usia Menopause. Puspa Swara: Jakarta

Lestary, Dewi. 2010. Seluk Beluk Menopause. Yogyakarta : Graha Ilmu

Notoatmodjo, S. 2012. Metodologi Penelitian Kesehatan. Cetakan Kedua. Edisi Revisi. Jakarta : Rineka Cipta

Proverawati, A. \& Sulistyawati, E. 2010. Menopause dan Syndrome Perimenopause. Yogyakarta : Nuha Medika

Setiadi, 2013. Konsep dan Praktek Penulisan Riset Keperawatan. Edisi Kedua. Yogyakarta : Graha Ilmu

Stuart, G. W. 2007. Buku Saku Keperawatan Jiwa. Jakarta: EGC

Tetti, Cecep. 2015. Konsep dan Aplikasi Relaksasi Dalam Perawatan Maternitas. Bandung: PT Refika Aditama.

Videbeck, S L. 2008. Buku Ajar Keperawatan Jiwa. Jakarta: EGC 